\author{
D.A. Bolysbek $^{*}$, B.K. Assilbekov ${ }^{(i)}$, Zh.K. Akasheva ${ }^{(i)}$, K.A. Soltanbekova \\ Satbayev University, Kazakhstan, Almaty \\ *e-mail: bolysbek.darezhat@gmail.com
}

\title{
ANALYSIS OF THE HETEROGENEITY INFLUENCE ON MAIN PARAMETERS OF POROUS MEDIA AT THE PORE SCALE
}

The study to analyze the heterogeneity of porous medium, especially its influence of main characteristics is conducted in this paper. For this goal computer versions of real porous models, which were available in open source, were used. These models contain several slices at three directions. Re-build and processing of models were performed using the Avizo Software. For analyzing the influence of the heterogeneity of porous medium on basic parameters, each model were divided into several geometrical pieces. These parameters were computed using computational method of pore network modelling (PNM) and Kozeny-Carman (KC) method with purpose of collation. Also, these two methods were collated with available data from direct numerical computation method (DNC). According to analyzing it was set a good match between PNM and DNC for sandstone models, also KC method showed a divergence with DNC. For carbonate models, a divergence was seen between PNM and DNC, and KC method showed very good match with DNC. The relationship between the parameters for each of piece shows inhomogeneous character for the carbonate model.

Key words: Pore Network Modelling, Direct Numerical Computation, Kozeny-Carman equation, permeability, porosity.

$$
\begin{gathered}
\text { Д.Ә. Болысбек*, Б.К. Асилбеков, Ж.К. Акашева, К.А. Солтанбекова } \\
\text { Сәтбаев университеті, Қазақстан, Алматы қ. } \\
\text { *e-mail: bolysbek.darezhat@gmail.com }
\end{gathered}
$$

Кеуекті ортаның біркелкі еместігінің оны сиппаттайтын параметрлерге әсерін кеуек масштабын зерттеу

Бұл мақалада кеуекті ортаның біртексіздігінің, әсіресе оның негізгі сипаттамаларға әсерін талдау үшін зерттеу жүргізілді. Осы мақсатта нақты кеуекті модельдердің компьютерлік нұсқалары пайдаланылды. Бұл үлгілерде үш бағытта бірнеше тілім бар. Үлгілерді қайта құру және өңдеу Avizo бағдарлама арқылы жүзеге асырылды. Ортаның біртексіздігінің негізгі параметрлерге әсерін талдау үшін әрбір модель бірнеше геометриялық бірдей бөліктерге бөлінді. Бұл параметрлер салыстыру үшін кеуек желісін модельдеу (КЖМ) және КозениКарман (KK) әдістерімен есептелді. Сонымен қатар, бұл екі әдіс тікелей сандық модельдеу (ТCM) әдісінің қолда бар деректерімен салыстырылды. Талдауға сәйкес, құмтас әлгілері үшін КЖМ және ТСМ арасында жақсы сәйкестік табылды, ал КK әдісі ТСМ әдісімен сәйкессіздікті көрсетті. Карбонатты модельдер үшін КЖМ және ТСМ әдісітірінің арасында сәйкессіздік байқалды, ал КK әдісі ТСМ өте жақсы сәйкестік көрсетті. Әрбір бөлік үшін параметрлер арасындағы байланыс карбонатты модель үшін гетерогенді сипат көрсетті.

Түйін сөздер: кеуекті желіні модельдеу, тікелей сандық модельдеу, Козени-Карман теңдеуі, өткізгіштік, кеуектілік.

$$
\begin{gathered}
\text { Д.Ә. Болысбек*, Б.К. Асилбеков, Ж.К. Акашева, К.А. Солтанбекова } \\
\text { Сатбаев Университет, Казахстан, г.Алматы } \\
\text { *e-mail: bolysbek.darezhat@gmail.com }
\end{gathered}
$$

Анализ влияния неоднородности на основные параметры пористых сред в масштабе пор 
В данной статье было проведено исследование по анализу неоднородности пористой среды, особенно ее влияния на основные характеристики. Для этой цели использовались компьютерные версии реальных пористых моделей, которые были доступны в открытом доступе. Эти модели содержат несколько срезов в трех направлениях. Перестроение и обработка моделей производились с помощью програмного обеспечния Аvizo. Для анализа влияния неоднородности пористой среды на основные параметры каждая модель разбивалось на несколько геометрически одинаковых частей. Эти параметры были рассчитаны с использованием вычислительного метода моделирования поровой сети (МПС) и метода Козени-Кармана $(\mathrm{KK})$ с целью сопоставления. Кроме того, эти два метода были сопоставлены с доступными данными из метода прямого численного моделирования (МЧМ). Согласно анализу, было установлено хорошее соответствие между МПС и МЧМ для моделей песчаника, в то время как метод KK показал расхождение с МЧМ. Для карбонатных моделей было замечено расхождение между МПС и МЧМ, в то время как метод КК показал очень хорошее совпадение с МЧМ. Соотношение между параметрами для каждых частей показало неоднородный характер для карбонатной модели.

Ключевые слова: моделирование поровой сети, прямое численное моделирование, уравнение Козени-Кармана, проницаемость, пористость.

\section{Introduction}

Determination of main parameters of pore media are important for different areas, for example, understanding the effect of various oil recovery factors with their further development. Researches on the core size models, for example, $\sim 4-6 \mathrm{~cm}$ are carried out on the basis of laboratory experiments. But laboratory tests have a number of disadvantages [1-4]. Real models of pore medium are very complex, what makes experimental tests inconvenient. It is not possible to carry out different tests on the same core models since experimental studies on the core are destructive $[5,6]$.

Thus, with the development of computerized technologies, in the last 10 to 20 years, the idea of a computer version of core (obtaining properties based on modeling at the pore scale) has received more and more attention. The computerized models of porous structure are used to determine properties by simulating processes on these models [7-9].

In the theory of soils, the concepts of fictitious and ideal soils are introduced. A fictitious soil is understood as a porous medium formed by solid balls (ball filling). An ideal soil is understood as a medium with pores in the form of a bundle of capillaries. The KC equation reflects the relationship between the porosity of the layer, the specific surface of the particles in the medium, the pressure difference, the length of the medium, and the filtration rate for this ideal structure. But this method is very inaccurate in order to their simplification of porous models into ideal cylinders (capillaries) which does not consider inhomogeneous character of the medium [10].

The most usable and developing methods at last decades for computation geometrical and hydrodynamic properties are PNM, DNC and Lattice-Boltzmann method from real computerized models of void material. Determining the main parameters by PNM method, the void material reconstructs into spherical and cylindrical system. But, reconstruction of real core models into cylinders and spheres includes inaccuracy in this method. Direct numerical computation is the most accurate numerical method. It is solved directly from the rendered computer versions of pore material and consider all the complexities of the geometry of the pore structure. The disadvantage of this method is that it requires large 
computer resources and the complexity of determining the boundary conditions [11-16]. The purpose of this work is to analyze the heterogeneity of pore structure of real porous material by dividing into identical pieces in four computer models. For each piece the computation of basic parameters of porous medium is performed using the PNM and KC methods. The characteristics of full-sized models are also computed and compared with direct numerical computation.

\section{Materials and methods}

\subsection{Materials}

The x-ray images of real porous models were obtained using micro-computed tomography. These samples are available on the website of the Imperial College of London [17]. Each sample contained 1000 slices in three directions with the appropriate resolution (Table 1).

Таблица 1: Properties of samples

\begin{tabular}{|l|l|l|l|}
\hline Core models & Voxels in 3 directions & Resolution & 2D slice of core \\
\hline Bentheimer sandstone & 1000 & & \\
\hline & & $3.0035 \mu \mathrm{m}$ & \\
\hline Doddington sandstone & 1000 & $2.6929 \mu \mathrm{m}$ & \\
\hline Estaillades carbonate & 1000 & & \\
\hline & & $3.31136 \mu \mathrm{m}$ & \\
\hline
\end{tabular}

The obtained data has already been pre-processed in order to reduction of noise and corner smoothing, therefore, in this study, image processing was reduced to building a 3D version of the samples. Avizo software was used to build a 3D model. The construction of a 3D model was carried out using the data, described in table-1. Number of voxels is $3 \mathrm{~d}$ pixel and each voxel have their own value as the resolution. After the construction of the 3D model, the "axis connectivity" operation was performed in the Avizo software. Axis Connectivity generates a binary image containing all paths connecting the two planes. This operation makes it possible to obtain information about the connected pores. After separation of pore spaces, the pore network model was constructed. A Pore Network Model is designed with store data that can be represented as linear lines in 3D space and that may be organized in networks of such multiple lines. Branching or endpoints of the network are called pores, the lines connecting pores are called throats. For each pore and throat, one or more scalar data items can be stored. According to the given data in Table 1, each of throats and pores have their own size. Pores and throats are represented as spheres and cylinders, respectively [19]. 


\subsection{Calculation of properties with different methods}

Calculation of the main parameters of the porous samples based on the network model was carried out with Avizo software. In this regard, it is assumed that the network is completely filled with only one phase. In a steady flow of an incompressible fluid, the mass conservation for each pore is described as [18]:

$$
\sum q_{i j}=0
$$

where $q_{i j}$ is the flow rate between pores $\mathrm{i}$ and $\mathrm{j}$, when the summation is performed over the entire pore $\mathrm{j}$ connected to the pore $\mathrm{i}$.

The relationship between pressure difference and flow rate is linear for laminar flow conditions:

$$
q_{i j}=q_{i j}\left(P_{i}-P_{j}\right)
$$

where $g_{i j}$ is the conductivity of the throat between pores i and $\mathrm{j}$. Since the conducting throats are represented by cylindrical pipes of radius $r_{i j}$ and length $l_{i j}$, the hydraulic conductivity is determined by Poiseuille's law, where $\mu$ is the viscosity of the fluid:

$$
q_{i j}=\frac{\pi}{8 \mu} \frac{r_{i j}^{4}}{l_{i j}} .
$$

By creating a pressure difference in the network, we obtain a linear system of equations, which is solved numerically: equations (1) and (2) lead to the following matrix equation:

$$
G \cdot P=S
$$

where $\mathrm{G}$ is the conductivity matrix, symmetric matrix of dimension $\mathrm{N}$, where $\mathrm{N}$ is the number of pores in the network; $\mathrm{P}$ is the vector of size $\mathrm{N}$ corresponding to the pressure in each pore; $\mathrm{S}$ is the vector of size $\mathrm{N}$, limited by the boundary conditions of the pressure at the inlet and outlet of the system. The total flow rate can then be calculated as:

$$
Q=\left(P_{i}-P_{j}\right) q_{i j}
$$

The permeability of the network is finally calculated from Darcy's law:

$$
k=\frac{Q}{\Delta P} \frac{\mu L}{A}
$$

where $\Delta \mathrm{P}$ is the pressure gradient, applied to the boundary $\left(\Delta \mathrm{P}=P_{\text {inlet }}-P_{\text {outlet }}\right), \mathrm{L}$ is the length of the network in the direction of flow.

Figure 1 illustrates demanding boundary conditions.

The hydraulic tortuosity is based on velocities derived from the previous calculation described above. Knowing the velocities in each throat, tortuosity is calculated by summing the lengths of all velocities divided by the sum of the projected velocities along the direction of flow:

$$
\tau=\frac{\sum_{i=0}^{n}\left\|v_{i}\right\|}{\sum_{i=0}^{n}\left\|v x_{i}\right\|},
$$


where $\mathrm{n}$ is the number of channels, $v_{i}$ is the velocity of the fluid, passing though the throat $\mathrm{i}$, and $v x_{i}$ is the projection of the velocity along the flow direction of the fluid passing through the throat.

The Kozeny-Carman equation of dependency relationship is written[20]:

$$
k=\frac{\phi^{3}}{c \tau^{2} S^{2}}
$$

where $\mathrm{S}$ is the specific surface area $(1 / \mathrm{m}) ; \phi$ is the porosity; c shows the Kozeny constant, for our case $\mathrm{c}=2.5$ (for the cylinder), $\tau$ is the tortuosity. The values of porosity, tortuosity and specific surface area were obtained from calculations carried out in Avizo.

\subsection{Influence of the heterogeneity}

To assess the influence of heterogeneity on main parameters of porous media, the 3D rendered images were divided into several same pieces. The division is illustrated on Figure 2.

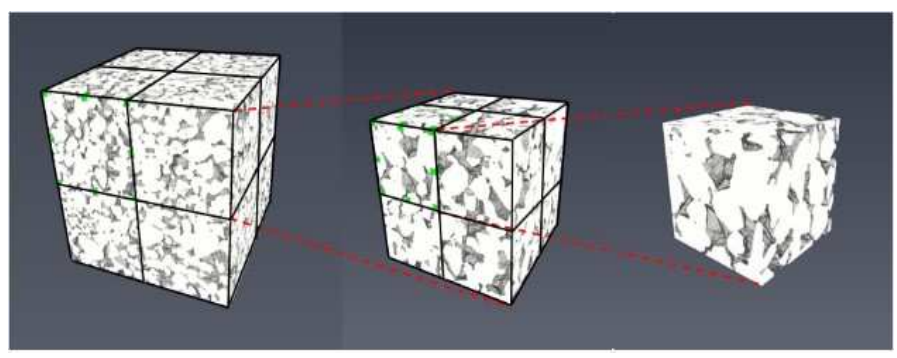

Figure 1: Dividing samples to the pieces

For each sample, calculations were carried out to determine the basic parameters using the methods described above. Also, for each piece of the sample, pore-network models and pore space separation were built.

\section{Results}

\subsection{Image reconstruction and comparison of methods}

The results of image processing and pore network generation are presented on Figure 3. The PNM method gives a good information about real characteristics of core sample, such as porosity, tortuosity, specific surface area.

There are results of computation for full sized computer models of real samples with $\Delta$ $\mathrm{P}=0.03 \mathrm{MPa}$ and $\mu=0.001 \mathrm{~Pa}^{*} \mathrm{~s}$ in the Table 2 .

The porosity, tortuosity, and specific surface area were used for the KC method. After that, two methods were compared with the value of DNC results from Imperial College of London [17] for the Bentheimer sandstone, Doddington sandstone and Estaillades carbonate samples (Figure 4). 


\subsection{Results of computation on the divided pieces of the models}

Each model was divided into 8 identical pieces. In turn, each piece was divided into 8 more pieces. However, the division into more and more pieces turned out to be difficult to assess the dependence of main parameters of the pore space among themselves due to the absence of connected pores and a decrease in the total porosity of small pieces. In this regard, the results of 8 pieces were used. For each piece, calculations to determine basic parameters were carried out to using the $\mathrm{KC}$ equation and pore network modeling method. Also, for each of the pieces, calculations of such parameters as porosity, tortuosity, specific surface area of the
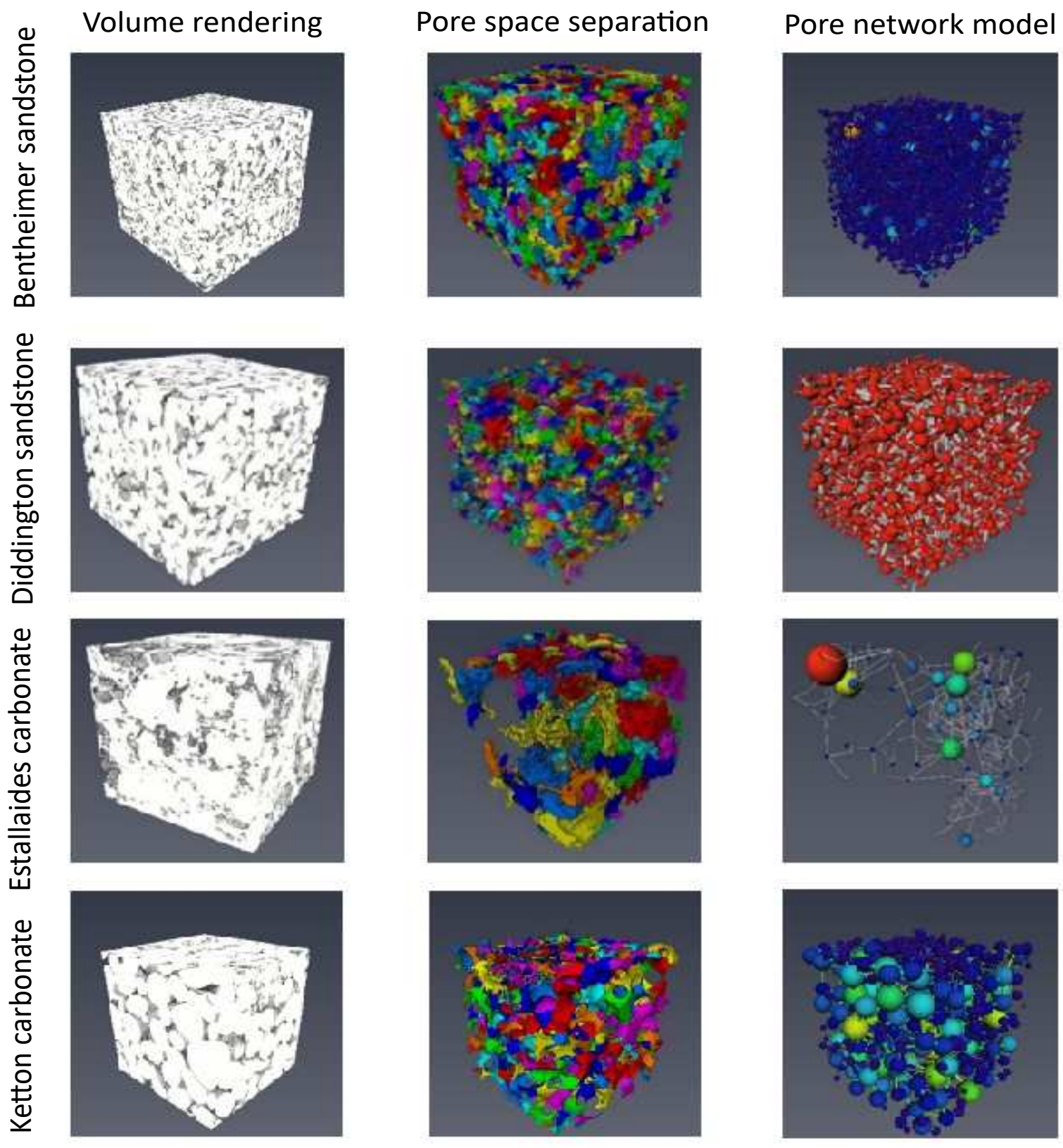

Figure 2: Results of basic steps of generating pore network model 
Таблица 2: Results of pore network modelling

\begin{tabular}{|l|l|l|l|l|l|}
\hline Type of core & $\begin{array}{l}\text { Permeability } \\
\left(\mu \mathrm{m}^{2}\right)\end{array}$ & $\begin{array}{l}\text { Total flow } \\
\text { rate }(\mu \mathrm{l} / \mathrm{s})\end{array}$ & Tortuosity & Porosity & $\begin{array}{l}\text { Specific Surface } \\
\text { Area }(1 / \mu m)\end{array}$ \\
\hline $\begin{array}{l}\text { Bentheimer } \\
\text { sandstone }\end{array}$ & 4,26 & 380,61 & 1,68 & 0,22 & 0,02 \\
\hline $\begin{array}{l}\text { Doddington } \\
\text { sandstone }\end{array}$ & 4,15 & 331,58 & 1,63 & 0,19 & 0,01 \\
\hline $\begin{array}{l}\text { Estaillades } \\
\text { carbonate }\end{array}$ & 0,33 & 32,11 & 1,58 & 0,10 & 0,01 \\
\hline $\begin{array}{l}\text { Ketton } \\
\text { carbonate }\end{array}$ & 7,34 & 656,36 & 1,57 & 0,13 & 0,01 \\
\hline
\end{tabular}

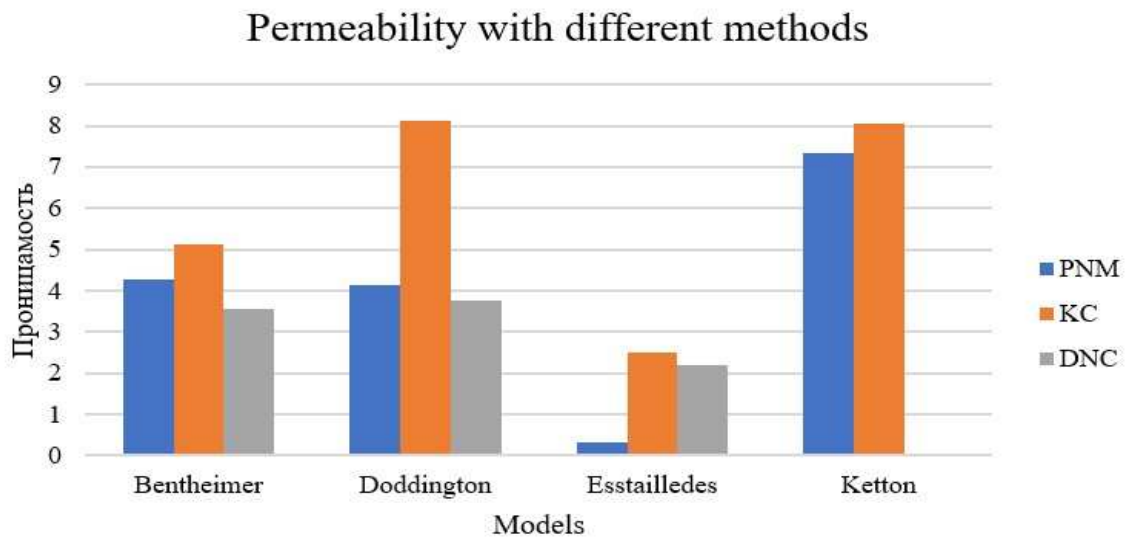

Figure 3: Comparison of different methods in computation

pore space were carried out. Figure 5 shows results of the dependence of permeability and porosity for each piece with two methods.

\section{Conclusions}

In this research results of analyzing of the effect of heterogeneity on basic parameters of real core models are presented. For that goal each of the computer model of real porous samples were divided into several parts (pieces), which was direct to asses the heterogeneity on properties of the medium. Results of calculation of these properties for each of the pieces, PNM method shown good match with the DNC for the Bentheimer and Doddington rocks, whereas in the empirical model, an increase in the value was observed. For the Estaillades, $\mathrm{KC}$ method was in a good match with the DNC, while PNM, on the contrary, began to move away from the value of the DNC method. This is clearly seen on Figure 5, where there was a division of the samples into pieces. The reason of deviation values for the carbonate Estaillades related with inhomogeneous character of the model which is shown in each piece. For example, for some pieces the estimation of parameters shown that there were no connected porous planes. These methods have its own advantages and disadvantages and at the same 


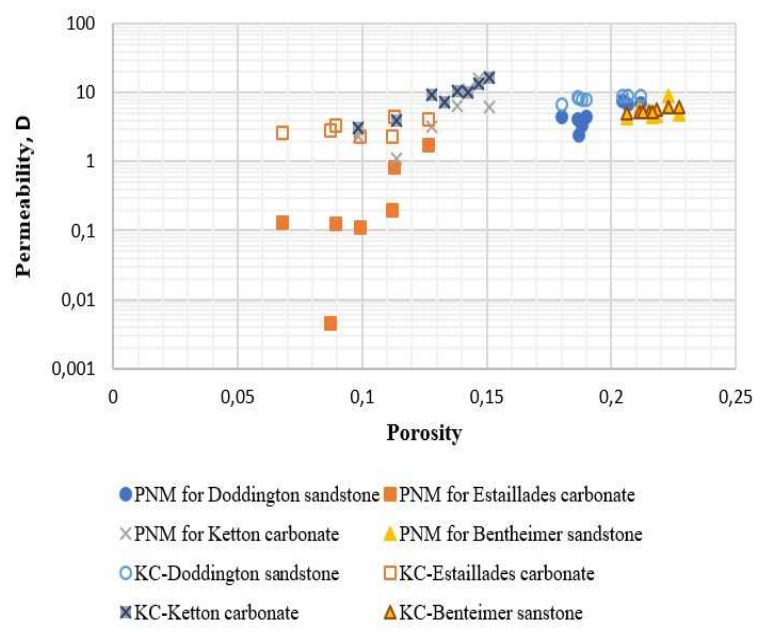

Figure 4: Dependence of porosity-permeability for each rock models' pieces computed with $\mathrm{PNM}$ and $\mathrm{KC}$ equation

time is actively developing, so it is not possible to establish the optimal one. The choice of method should be determined by the specific problem to be solved. Further works will be directed to the determination and parametrization of the factors for that influence to the development of the $\mathrm{KC}$ relationship by performing numerical experiments for computer models of real porous samples.

\section{Acknowledgement}

This research is funded by the Science Committee of the Ministry of Education and Science of the Republic of Kazakhstan (Grant No. AP09058419), which is gratefully acknowledged by the authors.

\section{References}

[1] Huang S.Y., Wu Y.Y., Meng X.B., "Recent advances on microscopic pore characteristics of low permeability sandstone reservoirs" Adv. Geo-Energy Res., (2018): 122-134, https://doi.org/10.26804/ager.2018.02.02.

[2] Rodriguez E.F., Giacomelli F., Vazquez A., "Permeability-porosity relationship in RTM for different fiberglass and natural reinforcements" J. Compos. Mater., 38 (2004): 259-268, https://hdl.handle.net/2122/2258.

[3] Lai J., Wang G.W., Cao J., "Investigation of pore structure and petrophysical property in tight sandstones" Mar. Pet. Geol., 91 (2018): 179-189.

[4] Mavko G., Nur A., "The effect of a percolation threshold in the Kozeny-Carman relation" Geophysics, 62 (1997): 13551673, https://doi.org/10.1190/1.1444251.

[5] Lai J., Wang G.W., Fan Z., "Insight into the pore structure of tight sandstones using NMR and HPMI measurements" Energy Fuels, 30 (2016): 13159-13178, https://doi.org/10.1021/acs.energyfuels.7b01816.

[6] Pape H., Clauser C., Iffland J., "Variation of permeability with porosity in sandstone diagenesis interpreted with a fractal pore space model" Pure Appl. Geophys., 157 (2000): 603-619, https://doi.org/10.1007/PL00001110.

[7] Civan F., "Scale effect on porosity and permeability: kinetics, model and correlation" AIChE J., 47 (2001): 271-287, https://doi.org/10.1002/aic.690470206. 
[8] Knackstedt M.A., Latham S., Madadi M., "Digital rock physics: 3D imaging of core material and correlations to acoustic and flow properties" Lead. Edge, 28(1) (2009): 28-33, https://doi.org/10.1190/1.3064143.

[9] Taron J., Elsworth D., Min K.B., "Numerical simulation of thermal-hydrologic-mechanical-chemical processes in deformable, fractured porous media" Int. J. Rock Mech. Min. Sci., 46(5) (2009): 842-854, https://doi.org/10.1016/j.ijrmms.2009.01.008.

[10] Blunt M.J., Branko B., Dong H., "Pore-scale imaging and modelling" Adv. Water Resour., 51(1) 2013: 197-216, https://doi.org/10.1016/j.advwatres.2012.03.003.

[11] Song R., Wang Y., Liu J., Cui M., Lei Y., "Comparative analysis on pore-scale permeability prediction on micro-CT images of rock using numerical and empirical approaches" Energy Sci. Eng., 7 (2019): 2842-2854, https://doi.org/10.1002/ese3.465.

[12] Dong H., Blunt M. J., "Pore-network extraction from micro-computerized-tomography images" Phys. Rev. E., 80 (2009): 036307, https://doi.org/10.1103/PhysRevE.80.036307.

[13] Dong H., Fjeldstad S., Alberts L., Roth S., Bakke S., Oren P.-E., "Pore network modelling on carbonate: a comparative study of different micro-ct network extraction methods" International symposium of the society of core analysts, Society of Core Analysts, (2008): 1-12.

[14] Delerue J.-F., Lomov S. V., Parnas R., Verpoest I., Wevers M., "Pore network modeling of permeability for textile reinforcements" Polym. Compos., 24 (3) (2003): 344-357, https://doi.org/10.1002/pc.10034.

[15] Balhoff M.T., Wheeler M.F., "A predictive pore-scale model for non-Darcy flow in porous media" SPE, 14(04) (2009): 579-587, https://doi.org/10.2118/110838-PA.

[16] Xiong Q.R., Todor B., Andrey P.J., "Review of pore network modelling of porous media: experimental characterisations, network constructions and applications to reactive transport" J. Contam. Hydrol., 192 (2016): 101-117, https://doi.org/10.1016/j.jconhyd.2016.07.002.

[17] Imperial College of London. Micro-CT Images and Networks. https://www.imperial.ac.uk/earthscience/research/research-groups/pore-scale-modelling/micro-ct-images-and-networks/.

[18] Dong H., "Micro-CT imaging and pore network extraction" $J$ (Doctor Thesis, London, UK: Imperial College London., (2007), https://www.imperial.ac.uk/media/imperial-college/faculty-of-engineering/earth-science-andengineering/recovered-files/33551696.PDF.

[19] Nordahl K., Ringrose P.S., "Identifying the representative elementary volume for permeability in heterolithic deposits using numerical rock models" Math. Geosci., 40 (2008): 753-771, https://doi.org/10.1007/s11004-008-9182-4.

[20] Latief F., Fauzi U., "Kozeny-Carman and empirical formula for the permeability of computer rock models" Int. J. Rock Mech. Min. Sci., 50 (2012): 117-123, https://doi.org/10.1016/j.ijrmms.2011.12.005. 